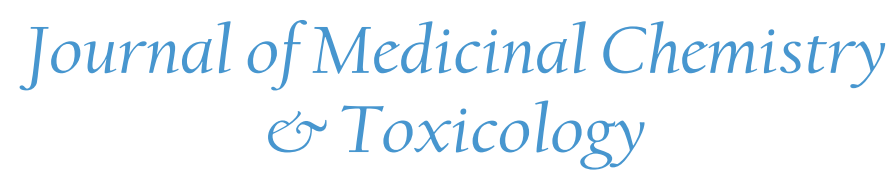

\title{
Antibacterial Activities of Nanoparticles of Titanium Dioxide, Intrinsic and Doped with Indium and Iron
}

\author{
Teklit Gebregiorgis Amabye ${ }^{1 *}$, Abrham Birara² \\ ${ }^{1}$ Department of Chemistry, Mekelle University College of Natural and Computational Science, Ethiopia \\ ${ }^{2}$ Department of Biology, Mekelle University, Ethiopia
}

*Corresponding authors: Teklit Gebregiorgis Amabye, Department of Chemistry, Mekelle University College of Natural and Computational Science, Ethiopia, E-mail: teklitgeb@gmail.com

\begin{abstract}
The need for new antimicrobial compounds has been attention on developing new and emerging materials based on nanoparticles with antimicrobial activity. The aim of this research was to evaluate the antibacterial activities of nanoparticles of titanium dioxide, intrinsic and doped with Indium and Iron in Escherichia coli and Staphylococcus aureus. The bacteriostatic effect of $\mathrm{TiO}_{2}$ nanoparticles (two samples), $\mathrm{TiO}_{2}: \mathrm{Fe}$ and $\mathrm{TiO}_{2}:$ In with concentrations of 50, $250500 \mu \mathrm{g} / \mathrm{ml}$. It was observed by optical density measurements. The bactericidal effect was determined by plate count agar Muller-Hinton, where they were incubated for 12 hours: $50 \mu \mathrm{l}$ of bacterial suspension (concentration $1.5 \times 10^{6}$ bacteria $/ \mathrm{ml}$ ), concentration $50 \mu \mathrm{l}$ of nanoparticles suspended at concentrations between 39 and $2500 \mu \mathrm{g} /$ $\mathrm{ml}$. Then, to 10 - 6 dilutions were made and plated on agar for colony counts. There were significant decreases $\mathrm{P}<0.05$ in the bacterial optical densities with respect to control, using $\mathrm{TiO}_{2}$ nanoparticles prepared with different contents of acetic acid at concentrations of 250 and $500 \mu \mathrm{g} / \mathrm{ml}$ versus $E$. coli and $S$. aureus. In the plate counts, there was a significant reduction, $\mathrm{P}<0.05$ in the number of $\mathrm{CFU}$ of $E$. coli using $\mathrm{TiO}_{2}$ nanoparticles $(50 \% \mathrm{AcAc})$ in concentrations 39 to $2500 \mu \mathrm{g} / \mathrm{ml}$; in the case of S. aureus decrease seen in concentrations 78 to $2500 \mu \mathrm{g} / \mathrm{ml}$. In both bacteria, we observed decreased bacterial growth with $\mathrm{TiO}_{2}$ nanoparticles at concentrations of $156-2500 \mu \mathrm{g} / \mathrm{ml}$. The two variants of preparing $\mathrm{TiO}_{2}$ nanoparticles have higher intrinsic activity against $E$. coli and $S$. aureus, while nanoparticles doped with Indium and Iron, not power the antibacterial effect.
\end{abstract}

Received Date: June 20, 2016

Accepted Date: July 5, 2016

Published Date: July 12, 2016

Citation: Amabye, T.G, et al. Antibacterial Activities of Nanoparticles of Titanium Dioxide, Intrinsic and Doped with Indium and Iron. (2016) J Med Chem Tox 1(1): 8- 14.

DOI: $10.15436 / 2575-808 X .16 .977$

Keywords: Dope; Nanoparticles; Titanium oxide

\section{Introduction}

The term nanoparticles (NP) is used to define particles smaller than $100 \mathrm{~nm}$ in diameter, which originate from two sources: primary (natural) and secondary or artificial (synthesized compounds), which may be organic or inorganic ${ }^{[1,2]}$. The Nanoparticles have different forms (helix, zigzag, belt, sphere, oval, prism, cube, helical or pillar) and can form agglomerations or be dispersed ${ }^{[3]}$. As NP become smaller, the percentage of surface atoms increases in relation to the total number of atoms ${ }^{[4]}$, its properties change considerably and have a melting point lower than that of a larger mass of the same composition ${ }^{[5]}$.

Actually, the nanoparticles are used in various areas such as medicine, pharmaceuticals, textiles and the electronics industry with the purpose of improving the quality of life ${ }^{[6]}$. Because of its photocatalytic activity they are used in the separation of water, energy production, air and water purification, sterilization of surfaces, synthesis of organic compounds and in the reduction environmental pollution. The NP used in medicine as metal oxide for coating of biomedical devices, such as prostheses, to prevent bacterial colonization and proliferation, with its catalytic activity ${ }^{[7]}$. Also, the NP apply for the preparation of drugs, protein detection and pathogen, treatment of tumors, separation and purification of biological molecules and cells ${ }^{[8]}$.

The organic NP have been used as bactericides, but its antibacterial properties are reduced at high temperatures ${ }^{[9]}$ and the inorganic type may have a general mechanism of toxicity against bacteria ${ }^{[10]}$.

One of the materials used in the last decades has been titanium dioxide $\left(\mathrm{TiO}_{2}\right)$ because it is not toxic, is easy to produce

Copyrights: (C) 2016 Amabye, T.G. This is an Open access article distributed under the terms of Creative Commons Attribution 
and cheap ${ }^{[11]}$. The morphological properties of titanium dioxide NPs greatly influence their applications ${ }^{[12]}$. $\mathrm{TiO}_{2}$ (occurs in nature) in three different forms: rutile, anatase and brookite. Of the three structures mentioned, the anatase NPs, are the most commonly used for photocatalysis. $\mathrm{TiO}_{2}$ nanomaterials are of interesting in a wide range of applications such as photocatalysis, dye sensititized solar cells, gas sensors, photochromic devices, photo degradation of organic compounds, deactivation of microorganisms, organic synthesis and cells culture ${ }^{[13]}$.

Metals such as platinum (Pt), silver $(\mathrm{Ag})$, gold $(\mathrm{Au})$, nickel $(\mathrm{Ni})$ and copper $(\mathrm{Cu})$ have been added to $\mathrm{TiO}_{2} \mathrm{NPs}$. These combinations have been very effective in improving photocatalysis ${ }^{[14]}$. $\mathrm{TiO}_{2} \mathrm{NPs}$ combined with silver $(\mathrm{Ag})$ in the presence of UV light have been showing greater effect against the growth of $E$. coli compared with $\mathrm{TiO}_{2} \mathrm{NPs}$ without $\mathrm{Ag}^{[1]]}$.

The inhibitory activity of the NPs, generally can be along two main pathways that are related to each other and in many cases occur simultaneously: 1) disruption of membrane potential and integrity and 2) production of reactive oxygen species (ROS), also known as oxygen-free radicals, the NPs acting as nanocatalysts ${ }^{[16]}$. The membrane damage occurs when NPs electro statically bind to the bacterial cell wall and membranes, leading to alteration of membrane potential, membrane depolarization and loss of integrity which, in turn, result in an imbalance of transport, impaired respiration, interruption of energy transduction and/or cell lysis, and eventually cell death. The distortion of the cell structure and expansion could cause destabilization of the membrane and increase membrane fluidity, which in turn increases the passive permeability and is manifested as a leak of several vital intracellular components such as ions, ATP, nucleic acids, sugars, enzymes and amino acids ${ }^{[17]}$.

The free radicals are induced indirectly due to respiratory chain disruption or directly by NPs themselves. A burst of ROS cause, via severe oxidative stress, damage the all the cell's macromolecules, leading to lipid peroxidation, alteration of proteins, inhibition of enzymes, and RNA and DNA damage. At high concentrations the ROS leading to cell death and low doses cause severe DNA damage and mutations ${ }^{[18]}$. In some cases where ROS production is induced by visible or UV light toxicity of the particles is photocatalytic ${ }^{[19]}$. It was observed that the $\mathrm{TiO}_{2} \mathrm{NP}$ combined with Ag plus UV light can be used for sterilization of vegetative cells of Bacillus, while $\mathrm{TiO}_{2}$ nanoparticles in the presence with UV light are effective against spores ${ }^{[20]}$.

In the present investigation we were evaluated the antimicrobial activity of nanoparticles of titanium dioxide intrinsic and doped with indium and iron against Gram-positive and Gram-negative pathogenic bacteria to assess the possibility of their being used as a new antibacterial strategy and environmental health.

\section{Material and Methods}

Nanoparticles $\mathrm{TiO}_{2}, \mathrm{TiO}_{2}:$ In and $\mathrm{TiO}_{2}: \mathrm{Fe}$ nanoparticles was prepared by the technique of Sol-Gel without reflux, using a mixture of titanium propoxide, acetic acid and Tween $80 \mathrm{R}$ on propanol, with the following molar proportions $4: 24: 1: 180$; based on the results of the synthesis of Choi et $a^{\left[l^{[21]}\right.}$ (2006). For doping with indium and iron we used in appropriate amounts $\mathrm{InCl}_{2}$ and $\mathrm{FeCl}_{3}$ in propanol, for obtaining $0.5 \%$ and $1 \%$ indium and $1.25 \%$ iron for the titanium ions. Also, a sample prepared with half acetic acid, half $\mathrm{TiO}_{2}(50 \% \mathrm{AcAc})$, that is to say $4: 12: 1: 180$. The samples were stirred until they became too viscous to continue. After drying in air at $200^{\circ} \mathrm{C}$ for 2 hours and calcined in air at $400^{\circ} \mathrm{C}$ for 8 hours in a muffle (Barnstead 1100). The powders obtained were ground in an agate mortar and reserved for tests of antibacterial activity. For comparison we used commercial $\mathrm{TiO}_{2}\left(\mathrm{P}_{25 \mathrm{Degussa}}\right)$.

Antibacterial activity: Bacterial growth curves were performed in order to observe the effect of different nanoparticles on strains of E. coli ATTC 25922 and Staphylococcus aureus ATCC 29213, growth following a 12 hour interval. The strains were seeded in MacConkey agar and mannitol salt agar respectively and incubated at $37^{\circ} \mathrm{C}$ until colonies have visible. From one or two colonies of bacteria suspended in $3 \mathrm{ml}$ of $0.9 \%$ saline solution prepared to a concentration of $0.5 \mathrm{McFarland}\left(1.5 \times 10^{8}\right.$ bacterial cells $\left./ \mathrm{ml}\right)$. The flasks were prepared for each layer containing $20 \mathrm{ml}$ of nutrient broth with concentrations of $0 \mu \mathrm{g} / \mathrm{ml}, 50 \mu \mathrm{g} / \mathrm{ml}, 250 \mu \mathrm{g} / \mathrm{ml}$ and 500 $\mu \mathrm{g} / \mathrm{ml}$ of $\mathrm{TiO}_{2}$ of nanoparticles, respectively. The flasks were inoculated with $100 \mu \mathrm{l}$ of the bacterial suspension of each strain and incubated at $37^{\circ} \mathrm{C}$ under continuous stirring to 250 r.p.m. for 24 hours. The Optical Density (OD) of the cultures at $600 \mathrm{~nm}$, an initial determination and readings every 2 hours was measured for 12 hours to monitor bacterial growth ${ }^{[9]}$.

Plate count: Bactericidal activity was evaluated and nanoparticles in bacterial strains were tested in bacterial growth curves. To determine the number of bacterial colonies growing with different concentrations of nanoparticles. From a dilute suspension 1: 100 concentration of $0.5 \mathrm{McF}$ arland nephelometer $\left(1.5 \times 10^{8}\right.$ bacteria), $50 \mu \mathrm{l}$ of this dilution was incubated in Eppendorf tubes, mixed with $50 \mu \mathrm{l}$ of suspensions of nanoparticles of $\mathrm{TiO}_{2}, \mathrm{TiO}_{2}(50 \% \mathrm{AcAc})$ and $\mathrm{P} 25 \mathrm{D}$ at concentrations of 39 to $2500 \mu \mathrm{g} / \mathrm{ml}$ and incubation at $37^{\circ} \mathrm{C}$ for $12 \mathrm{hrs}$, during this time the tubes were shaken every hour in vortex. To perform the plate count preparations were diluted to $10-6$ and plated on Mueller Hinton agar. After incubation for 24 hrs colony counting was performed, the results of which were multiplied by the dilution factor to obtain the total number of CFU per $100 \mathrm{ml}$.

Analysis of results: Experiments were performed in triplicate. Statistical analysis was performed using STATA v.12.0 software, determining mean and standard deviation of the O.D determined between repetitions of the experiments; also p-values were determined using the Student $t$ test between different experimental groups over control. The graphics were made in the program GraphPad PRIMS. 


\section{Results}

The nanoparticles synthesized in the laboratory were characterized using SEM images. The particle size of TiO ${ }_{2}$ is approximately of $50 \mathrm{~nm}$ (Figure 1). Antibacterial activity of 6 samples of $\mathrm{TiO}_{2}$ nanoparticles were evaluated on the growth of $E$. coli ATCC 25922 and S. aureus ATCC 29213 in liquid medium. The decrease in O.D of experimental cultures (nanoparticles/bacteria) from the control cultures (bacteria without nanoparticles) was the indicator of the effect of nanoparticles. The following conversion factors of O.D was used CFU/ml: 1 O.D $600 \mathrm{~nm} \mathrm{E.} \mathrm{coli}=1 \times 10^{9} \mathrm{CFU} / \mathrm{ml}[22]$ and 1 O.D $600 \mathrm{~nm} \mathrm{S.} \mathrm{aureus}=1.5 \times 10^{8} \mathrm{CFU} / \mathrm{ml}^{[23]}$.

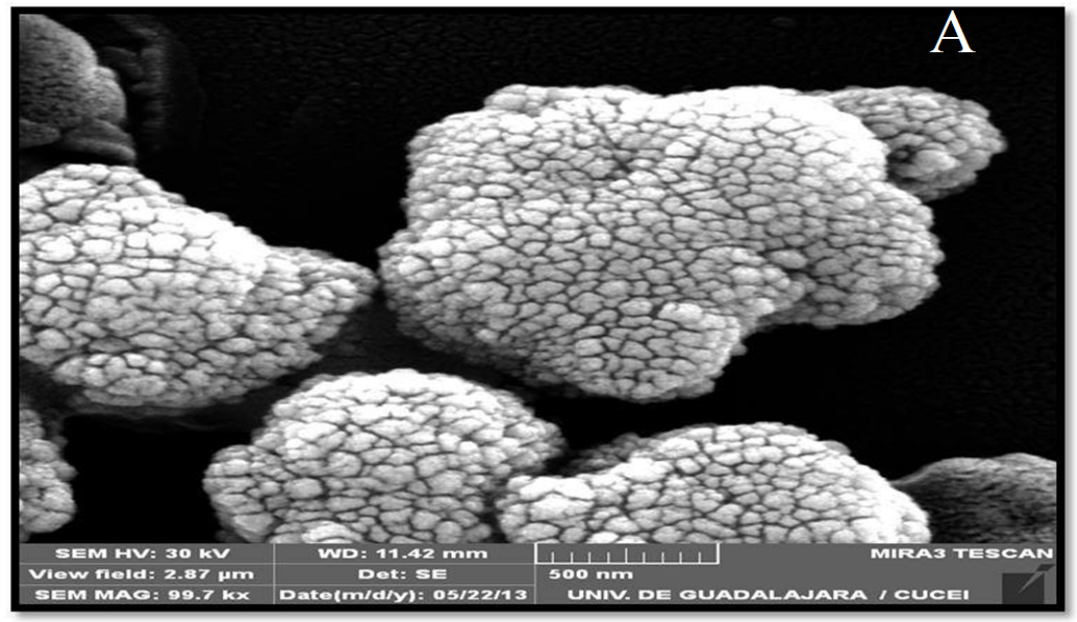

B

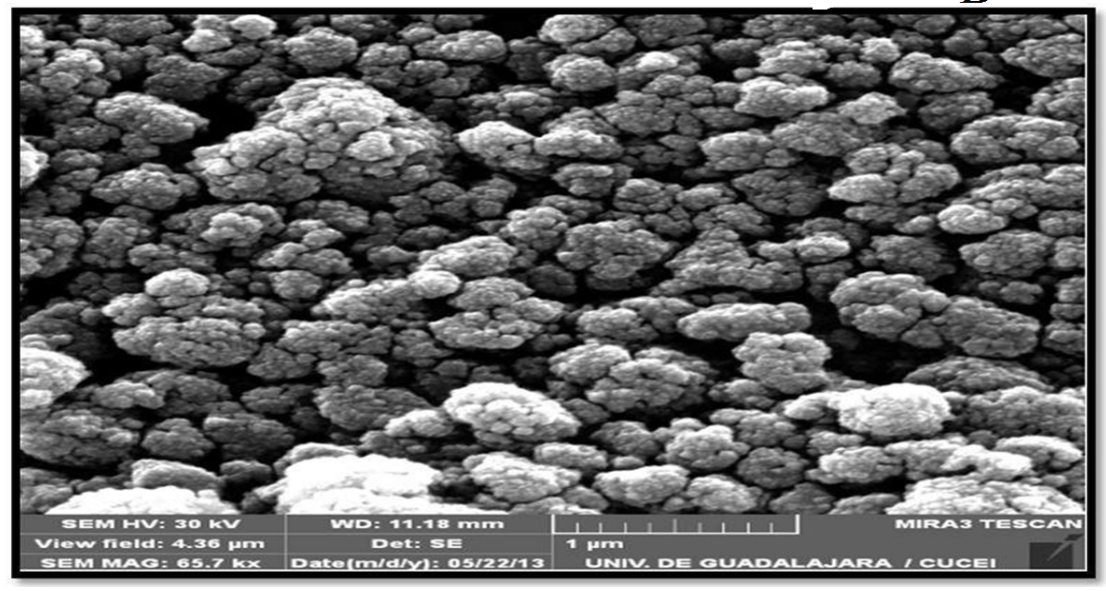

Figure 1: A) Nanoparticles of $\mathrm{TiO}_{2}$ B) Nanoparticles of $\mathrm{TiO}_{2}(50 \%$ AcAc $)$

In the figure 2 the bacterial growth of E. coli ATCC 25922 and $S$. aureus ATCC 29213 is observed in the presence of TiO 2 NPs. E. coli had a decrease of optical density in the exponential phase between 4 to 6 hours using concentrations of 250 and $500 \mu \mathrm{g} /$ $\mathrm{ml}$, and which became more evident after 6 hours of growth. For $S$. aureus, using concentrations of 50,250 and $500 \mu \mathrm{g} / \mathrm{ml} \mathrm{showed}$ an altered decreasing growth between 4 to 8 hours.

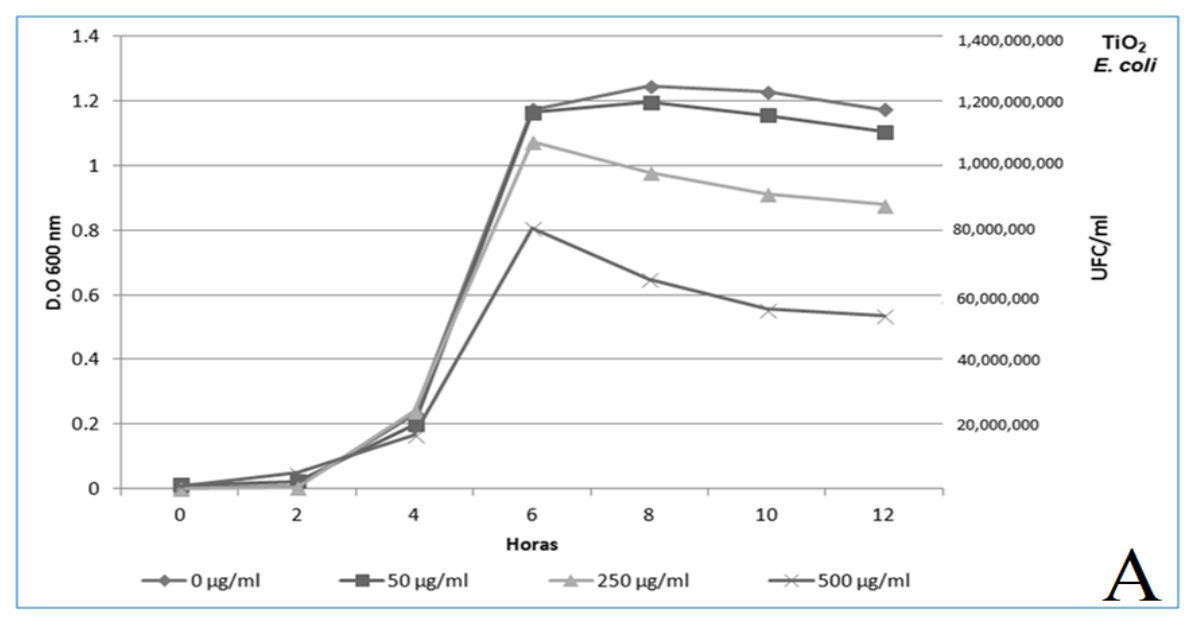




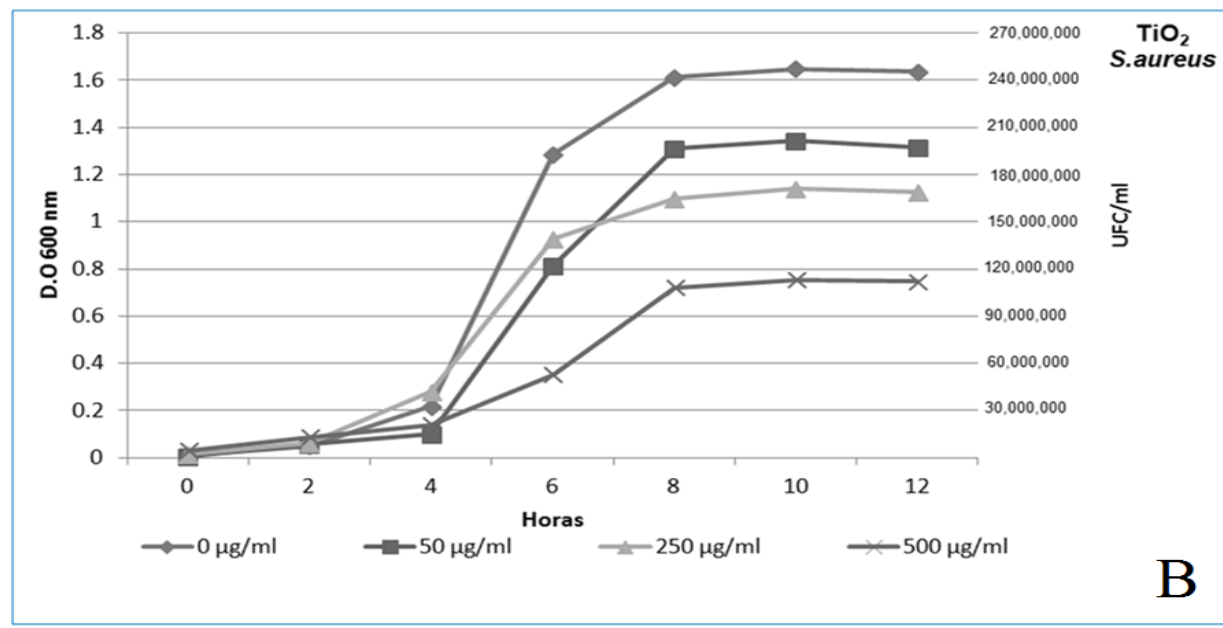

Figure 2: Bacterial growth with different concentrations of nanoparticles $\mathrm{TiO}_{2}$. (A) Escherichia coli ATTC 25922 (B) Staphylococcus aureus ATCC 29213.

With the nanoparticles of $\mathrm{TiO}_{2}(50 \% \mathrm{AcAc})$ we observed an antibacterial effect on $E$. coli using concentrations 250 and 500 $\mu \mathrm{g} / \mathrm{ml}$ in the exponential phase between 4 and 8 hours of growth. While for $S$. aureus only with concentrations of $500 \mu \mathrm{g} / \mathrm{ml}$ was noticeable antibacterial activity between 6 to 12 hours of growth. With commercial nanoparticles Degussa P25, a decrease in optical density of $E$. coli and $S$. aureus between 4 and 6 hours of growth was observed using the three concentrations, but the effect it was greater at concentrations of 250 and $500 \mu \mathrm{g} / \mathrm{ml}$ compared with $\mathrm{TiO}_{2}$ prepared in this study.

By employing doped nanoparticles of $\mathrm{TiO}_{2}: \mathrm{In}(1 \%), \mathrm{TiO}_{2}: \mathrm{In}(0.5 \%), \mathrm{TiO}_{2}: \mathrm{Fe}(1.25 \%)$ there was no significant decrease in optical density with the three concentrations used for $E$. coli. However, a significant decrease was observed in $S$. aureus at concentrations of $500 \mu \mathrm{g} / \mathrm{ml}$ of the nanoparticles of $\mathrm{TiO}_{2}: \operatorname{In}(0.5 \%)$.

In order to compare the antimicrobial effect of nanoparticles studied using growth curves $p$ value were calculated. The effect of the nanoparticles at a concentration of $500 \mu \mathrm{g} / \mathrm{ml}$ showed antibacterial activity, which was more evident in nanoparticles of $\mathrm{TiO}_{2}, \mathrm{TiO}_{2}(50 \% \mathrm{AcAc})$ and $\mathrm{P} 25$, a significant value $(\mathrm{P}<0.05)$ in E. coli. The concentration of $\mathrm{TiO}_{2}:$ In $(0.5 \%)$ also had an effect on S. aureus (Figure 3).
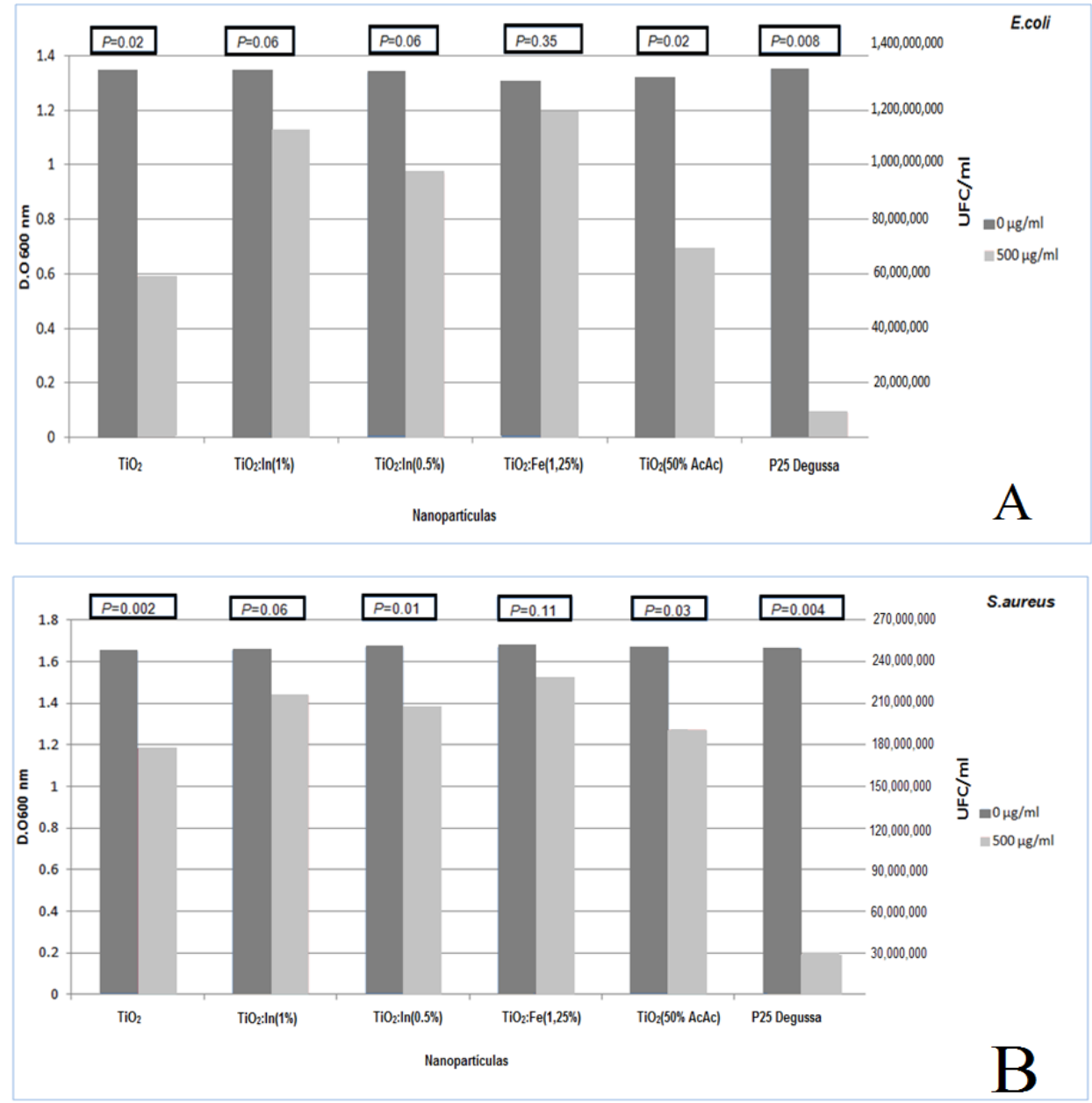
Figure 3: Optical density and Colony Forming Units / $\mathrm{ml}$ of bacterial growth after 12 hours incubation with a concentration of $500 \mu \mathrm{g} / \mathrm{ml}$, of intrinsic and doped nanoparticles.

A) Escherichia coli ATTC 25922 B) Staphylococcus aureus ATCC 29213

The bactericidal activity of the nanoparticles in the studied bacterial strains was determined by the bacterial colonies growing number being challenged at different nanoparticles concentrations. We counted in a range of 30 - 200 colonies by dilutions made. In controls without nanoparticles of $E$. coli and $S$. aureus, we determined $179 \times 10^{8} \mathrm{UFC} / \mathrm{ml}$; we compared with viable counts of various concentrations of nanoparticles and obtained the $\mathrm{p}$ value. The Table 1 shown $\mathrm{p}$ values of different concentrations for $E$. coli, the $\mathrm{P} 25$ commercial nanoparticle showed significant values low $(\mathrm{P}<0.05)$ at all concentrations. $\mathrm{p}$ values against $S$. aureus are shown in Table 2.

Table 1: Values of p plate count against E. coli

\begin{tabular}{|c|c|c|c|}
\hline $\begin{array}{l}\text { Nanoparticle } \\
\text { oncentration }(\boldsymbol{\mu g} / \mathbf{m l})\end{array}$ & $\begin{array}{c}\mathbf{T i O}_{2} \\
\mathbf{p ~ v a l u e}\end{array}$ & $\begin{array}{c}\mathbf{T i O}_{2} \\
\mathbf{( 5 0 \%} \text { AcAc) } \mathbf{p} \text { value }\end{array}$ & $\begin{array}{c}\text { P25 } \\
\text { p value }\end{array}$ \\
\hline 2500 & 0.0118 & 0.0055 & 0.0055 \\
\hline 1250 & 0.0131 & 0.0089 & 0.0089 \\
\hline 625 & 0.0232 & 0.0097 & 0.0097 \\
\hline 312.5 & 0.0259 & 0.0146 & 0.0146 \\
\hline 156.25 & 0.0406 & 0.0187 & 0.0187 \\
\hline 78.125 & 0.0515 & 0.0240 & 0.0240 \\
\hline 39.062 & 0.0760 & 0.0374 & 0.0374 \\
\hline
\end{tabular}

Table 2: Values of p plate count against S.aureus

\begin{tabular}{|c|c|c|c|}
\hline $\begin{array}{l}\text { Nanoparticle } \\
\text { concentration }(\boldsymbol{\mu g} / \mathbf{m l})\end{array}$ & $\begin{array}{c}\mathbf{T i O}_{2} \\
\mathbf{p ~ v a l u e}\end{array}$ & $\begin{array}{c}\mathbf{T i O}_{\mathbf{2}} \\
\mathbf{( 5 0 \%} \mathbf{A c A c}) \mathbf{p} \text { value }\end{array}$ & $\begin{array}{c}\text { P25 } \\
\mathbf{p} \text { value }\end{array}$ \\
\hline 2500 & 0.0133 & 0.0095 & 0.0026 \\
\hline 1250 & 0.0148 & 0.0102 & 0.0029 \\
\hline 625 & 0.0202 & 0.0150 & 0.0031 \\
\hline 312.5 & 0.0315 & 0.0165 & 0.0135 \\
\hline 156.25 & 0.0489 & 0.0251 & 0.0119 \\
\hline 78.125 & 0.0752 & 0.0435 & 0.0202 \\
\hline 39.062 & 0.1257 & 0.0552 & 0.0374 \\
\hline
\end{tabular}

\section{Discussion}

Actually the search for new alternatives for application in biomedicine such as the elimination of bacterial infections, mainly nosocomial type, has caused a significant interest in the development of nanomaterials with antimicrobial capacity. During this study the intrinsic antibacterial properties of $\mathrm{TiO}_{2}$ nanoparticles were evaluated and doped $\mathrm{TiO}_{2}: \mathrm{Fe}$ and $\mathrm{TiO}_{2}$ : In at different concentrations to determine which presented the best antibacterial activity against the growth in culture of E. coli (ATCC 25922) and S. aureus (ATCC 29213); used as test organisms for conducting experiments.

The carrying out growth in a liquid medium helped us to evaluate the bacteriostatic effect of various nanoparticles. The most significant results were obtained on both strains using $\mathrm{TiO}_{2}$ and $\mathrm{TiO}_{2}(50 \% \mathrm{AcAc})$ nanoparticles at concentrations of $500 \mathrm{mg} /$ $\mathrm{ml}$. The quantitative test plate count allowed us to estimate the antibacterial activity through the survival ratio calculated from the number of viable cells which formed colonies on Muller Hinton agar plates (CFU $\mu \mathrm{g} / \mathrm{ml})$. The results were relevant to the two intrinsic synthesized nanoparticles that were used $\mathrm{TiO}_{2}$ and $\mathrm{TiO}_{2}(50 \%$ AcAc).

The $\mathrm{TiO}_{2}$ nanoparticles (50\% AcAc) showed the best antibacterial activity; even surpassing control nanoparticles, when using these nanoparticles, smaller amounts CFU/ml were obtained. This shows that it has a greater bactericide effect on the bacterial species, a fact which can also be directly related to the percentage of acetic acid used in the synthesis of these nanoparticles. The use of $50 \%$ acetic acid favored the bactericide effect of $\mathrm{TiO}_{2}$ unlike doping of $\mathrm{TiO}_{2}$ nanoparticles with iron and indium. In a study by Hernandez Enriquez et al., ${ }^{[24]}$ in 2008, a synthesis of $\mathrm{TiO}_{2}$ nanoparticles were made, with varied amounts of acetic acid to analyze the physicochemical properties of nanoparticles and it was found that when using $1.125 \mathrm{ml}$ of acetic acid the nanoparticles reached a size of $7.2 \mathrm{~nm}$, smaller than the $16 \mathrm{~nm}$ commercial nanoparticles. Therefore, the amount of acetic acid influences nanoparticles size. It should be noted that compared to bacterial growth in liquid medium in the presence of $\mathrm{TiO}_{2}$ and $\mathrm{TiO}_{2}$ nanoparticles (50\% AcAc) in 3 different concentrations $(50,250$ and $500 \mu \mathrm{g} / \mathrm{ml})$, lower growth was observed in E. coli than $S$. aureus. This indicates increased resistance of the latter due to the large amount of peptidoglycan that it has, which gives greater protection; whereas $E$. coli has only a thin layer of peptidoglycan and lipopolysaccharide allowing greater interaction of the nanoparticles with these bacterial components.

The antibacterial activity of the nanoparticles used may be related to the binding of the nanoparticles to the outer membrane of $E$. coli causing inhibition of active transport and eventually inhibiting RNA, DNA and protein synthesis, leading to cell 
death. Research has been conducted indicating the possible mechanisms involved in the interaction of nanoparticles with biological macromolecules, which indicate that bacteria have a negative charge, while the metal oxide nanoparticles have a positive charge. This causes an attraction between bacteria-nanoparticles and leads to oxidation of the bacteria. The nanoparticles react with the thiol group (-SH) of the proteins in the bacterial cell wall, causing inactivation of transport proteins nutrients, reducing cell permeability and causing death ${ }^{[25]}$.

These mechanisms of action are proposed as being responsible for the antibacterial activity of the NP which is analyzed in this paper. Most researchers have demonstrated so far the mechanism of photocatalytic elimination of different microorganisms using titanium dioxide with UV or sunlight. This is the only mechanism of action resulting in the loss of structural integrity of the cells membranes in the presence of $\mathrm{TiO}_{2}$ nanoparticles, although lipid peroxidation by the release of reactive oxygen species such as hydroxyl radicals and superoxide has also been proposed ${ }^{[26]}$.

The results obtained in this study are compared with two studies; the first made in 2010, for Reazaei-Zarchi et al ${ }^{[9]}$, which determine the antibacterial activity of $\mathrm{TiO}_{2}$ nanoparticles against E. coli, without the presence of UV rays, using concentrations of 500 and $1000 \mu \mathrm{g} / \mathrm{ml}$; obtaining a value of $\mathrm{p}<0.05$ at these concentrations. This result was the same as that obtained in the present work, since a significant bacterial reduction $(\mathrm{p}=0.02)$ was observed with $\mathrm{TiO}_{2}$ nanoparticles at a concentration of $500 \mu \mathrm{g} / \mathrm{ml}$ against the same bacteria.

A second study, by Mohammed Sadiq et al in 2010[27], where the effect of $\mathrm{TiO}_{2}$ nanoparticles on the growth of E. coli, Pseudomonas aeruginosa and Bacillus subtilis was studied and mentions that at a concentration of $100 \mu \mathrm{g} / \mathrm{ml}$ there was an inhibitory effect for 3 bacteria, because logarithmic growth phase showed a marked decrease in bacterial optical density, similar to the effect observed in this work on E. coli, but at concentrations of $250 \mu \mathrm{g} / \mathrm{ml}$ and $500 \mu \mathrm{g} / \mathrm{ml}$.

In the case of the nanoparticles doped with Indium $(0.5 \%$ and $1 \%)$ decreased antibacterial activity. In the study conducted in 2011 by Martínez and Gómez ${ }^{[28]}$ it is mentioned that there must be an optimum doping in the synthesis of nanoparticles that causes a phase transition from anatase to rutile, resulting in a decrease in the size of these nanoparticles and promoting their properties. So it is possible that in future studies increasing or decreasing doping it may be possible find the right ratio that favors their antibacterial effect.

In the case of nanoparticles of $\mathrm{TiO}_{2}: \mathrm{Fe}(1.25 \%)$, there was not a significant decrease in optical density for $E$. coli and $S$. aureus, and $\mathrm{p}$ values greater than 0.05 obtained at the three concentrations used. As doping with $\mathrm{Fe} 1.25 \%$ decreases the antibacterial activity of nanoparticles of $\mathrm{TiO}_{2}$. The null antibacterial activity by these nanoparticles could relate to the assimilation of $\mathrm{Fe}$ used in the metabolism of bacteria, since iron is an essential micronutrient for normal growth of most microorganisms. It should be mentioned that the bacteria have different mechanisms to capture environmental iron or a host. In Gram negative bacteria, the cell possesses outer membrane complex receptors that supply the energy required for iron transport (Ton complex) which allow the iron to pass through the outer membrane and is internalized into the cytoplasm via the cell membrane. In Gram positive bacteria, the iron binding to lipoproteins anchored in the cytoplasmic membrane, thus must traverse this membrane and peptidoglycan ${ }^{[29]}$. Therefore doping with iron nanoparticles appears not to be a favorable option, at least when used as an antibacterial agent.

One limitation to study the antibacterial activity of nanoparticles is the precipitation of these. But with this work forms a basis for assessing the antibacterial activity of nanoparticles with potential biomedical applications.

\section{Conclusion}

In conclusion nanoparticles of $\mathrm{TiO}_{2}$ and $\mathrm{TiO}_{2}(50 \% \mathrm{AcAc})$ have a higher activity against $E$. coli and $S$. aureus, and doping $\mathrm{TiO}_{2}$ with Indium and Iron do not significantly enhance the antibacterial effect. The concentration of 250 and $500 \mu \mathrm{g} / \mathrm{ml}$ the intrinsic nanoparticles significantly alter bacterial growth in the exponential phase and have a greater antibacterial effect on $E$. coli and $S$. aureus; $\mathrm{TiO}_{2}(50 \% \mathrm{AcAc})$ nanoparticles have a greater bactericide effect.

\section{References}

1. Kaluza, S., Balderhaar, J.K., Orthen, B., et al. Literature Review - Workplace exposure to nanoparticles. (2009) EU-OSHA-European Agency for Safety and Health at Work.

2. Sanvicens, N., Marco, M.P. Multifunctional nanoparticles - properties and prospects for their use in human medicine. (2008) Trends Biotechnol 26(8): 425-433.

3. Buzea, C., Pacheco, I.I., Robbie, K. Nanomaterials and nanoparticles: Sources and toxicity. (2007) Biointerphases 2(4): 17-71.

4. Li, W., Zeng, T. Preparation of $\mathrm{TiO}_{2}$ anatase nanocrystals by $\mathrm{TiCl}_{4}$ Hydrolysis with Additive $\mathrm{H}_{2} \mathrm{SO}_{4}$. (2011) PloS one 6(6): e21082.

5. Grande, A.H. Nanotecnología y nanopartículasmagnéticas: La física actual enlucha contra la enfermedad. (2007) Rev R Acad Cienc Exact Fís Nat 101(2): 321-327.

6. Tsuzuki, T. Commercial scale production of inorganic nanoparticles. (2009) Int J Nanotech 6(5): 567-578.

7. Visai, L., De Nardo, L., Punta, C., et al. Titanium oxide antibacterial surfaces in biomedical devices. (2011) Int J Artif Organs 34(9): 929-946.

8. Wang, J., Byrne, J.D., Napier, M.E., et al. More effective nanomedicines through particle design. (2011) Small 7(14): $1919-1931$.

9. Rezaei-Zarchi, S., Javed, A., Ghani, M.J., et al. Comparative Study of Antimicrobial Activities of $\mathrm{TiO}_{2}$ and CdO Nanoparticles against the Pa thogenic Strain of Escherichia coli (2010) Iran J Pathol 5(2): 83-89.

10. Taylor, E., Webster, T.J. Reducing infections through nanotechnology and nanoparticles. (2011) Int J Nanomedicine 6: 1463-1473.

11. Xie, Y., Heo, S.H., Yoo, S.H., et al. Synthesis and Photocatalytic Activity of Anatase $\mathrm{TiO}_{2}$ Nanoparticles-coated Carbon Nanotubes. (2009) Nanoscale Res Lett 5(3): 603-607. 
12. Yan, M., Chen, F., Zhang, J., et al. Preparation of controllable crystalline titania and study on the photocatalytic properties. (2005) J Phys Chem B 109(18): 8673-8678.

13. Banerjee, A.N. The design, fabrication, and photocatalytic utility of nanostructured semiconductors: focus on $\mathrm{TiO}_{2}$-based nanostructures. (2011) Nanotechnology Sci Appl 4: 35-65.

14. Gupta, S.M., Tripathi, M. A review of $\mathrm{TiO}_{2}$ nanoparticles. (2011) Chin Sci Bull 56: 1639-1657.

15. Ashkarran, A.A., Aghigh, S.M., Farahani, N.J. Visible light photo-and bioactivity of $\mathrm{Ag} / \mathrm{TiO}_{2}$ nanocomposite with various silver contents. (2011) Current Applied Physics 11(4): 1048-1055.

16. Beyth, N., Houri-Haddad, Y., Domb, A., et al. Alternative Antimicrobial Approach: Nano-Antimicrobial Materials. (2015) Evidence-Based Complementary and Alternative Medicine 1-16.

17. Díaz-Visurraga, J., Gutiérrez, C., von Plessing, C., et al. Metal nanostructures as antibacterial agents. (2011) Science against microbial pathogens: communicating current research and technological advances 210-218.

18. Sondi, I., Salopek-Sondi, B. Silver nanoparticles as antimicrobial agent: a case study on E. coli as a model for Gram-negative bacteria. (2004) J Colloid Interface Sci 275(1): 77-182.

19. Park, S.M., Kim, H.S., Yu, T.S. Effect of titanium ion and resistance encoding plasmid of Pseudomonas aeruginosa ATCC 10145. (2006) J Microbiol 44(3): 255-262.

20. ThiTuyetNhung, L., Nagata, H., Takahashi, A., et al. Sterilization effect of UV light on Bacillus spores using TiO ${ }_{2}$ films depends on wavelength. (2012) J Med Invest 59(1-2): 53-58.

21. Choi, H., Stathatos, E., Dionysiou, D.D. Synthesis of nanocrystalline photocatalytic $\mathrm{TiO}_{2}$ thin films and particles using sol-gel method modified with nonionic surfactants. (2006) Thin Solid Films 510(1-2): 107-114.

22. Chang, Y.C., Yang, C.Y., Sun, R.L., et al. Rapid single cell detection of Staphylococcus aureus by aptamer-conjugated gold nanoparticles. (2013) Sci Rep 3: 1863

23. Ausubel, F., Brent, R., Kingston, R.E., et al. Short protocols in Molecular Biology. (2002) $5^{\text {th }}$ ed Editorial While, United Stated of America.

24. Hernández Enríquez, J.M., García Serrano, L.A., ZeifertSoares, B.H., et al. Síntesis y Caracterización de Nanopartículas de $\mathrm{N}_{-} \mathrm{TiO}-\mathrm{Anatasa}_{2}$ (2008) Superficies y Vacío 21(4): 1-5.

25. Zhang, H., Chen, G. Potent antibacterial activities of $\mathrm{Ag} / \mathrm{TiO}_{2}$ nanocomposite powders synthesized by a one-pot sol-gel method. (2009) Environ Sci Technol 43(8): 2905-2910.

26. Allahverdiyev, A.M., Abamor, E.S., Bagirova, M., et al. Antimicrobial effects of $\mathrm{TiO}_{2}$ and $\mathrm{Ag}_{2} \mathrm{O}$ nanoparticles against drug-resistant bacteria and Leishmania parasites. (2011) Future Microbiol 6(8): 933-940.

27. Mohammed Sadiq, I., Chandrasekaran, N., Mukherjee, A. Studies on effect of TiO2 nanoparticles on growth and membrane permeability of Escherichia coli, Pseudomonas aeruginosa, and Bacillus subtilis. (2010) Current Nanoscience 6(4): 381-387.

28. Martínez, L.M.T., Gómez, M.A.R. Estudio de las propiedadesestructurales, texturales y catalíticas de $\mathrm{TiO}_{2}$ dopado con indio y niquel. (2011) Ingenierias 53(14): $23-34$.

29. Köster, W. ABC transporter-mediated uptake of iron, siderophores, heme and vitamin B12. (2001) Res Microbiol 152(3-4): 291-301.

Ommega Online Publisher

Journal of Medicinal Chemistry \& Toxicology

Short Title : J Med Chem Toxicol
ISSN No: 2575-808X

E-mail: medchemtoxic@ommegaonline.org

website: www.ommegaonline.org 